Boise State University

ScholarWorks

Public Policy and Administration Faculty

Publications and Presentations

Department of Public Policy and Administration

8-1-2017

Local Revenue Structure Under Economic Hardship: Reliance on Alternative Revenue Sources in California Counties

Sanghee Park

Boise State University 


\title{
Local Revenue Structure Under Economic Hardship: Reliance on Alternative Revenue Sources in California Counties
}

\author{
Sanghee Park \\ Assistant Professor \\ Department of Public Policy and Administration \\ School of Public Service \\ Boise State University \\ 1910 University Dr. ERB \#5139, Boise, ID 83725 \\ sangheepark@boisestate.edu
}

Sanghee Park is an assistant professor in the Department of Public Policy and Administration, School of Public Service at Boise State University. Her research efforts include public personnel/financial management, state and local government in relation to political institutions. Her articles have appeared in such journals as the Journal of Public Policy, Public Performance Management Review, International Public Management Journal, and American Review of Public Administration.

\begin{abstract}
This article investigates how a worsening economy affects local revenue structure, and whether the impact is moderated by the fiscal relationship within higher levels of government. The revenue potential of nontax sources_-fees/charges and fines/forfeitures—is considerable for local governments under economic hardship. With the panel data from California counties over a period of 11 years (2000-2010), this article shows that reliance on nontax revenue largely depends on the economic and fiscal factors that vary across counties, and the effect of economy is contingent on local dependence on intergovernmental transfers. Counties are likely to raise nontax revenue when the economy worsens and their transfer-dependence increases, while the marginal effect of the economic indicators changes from negative to positive as transferdependence increases. This article illuminates the characteristics of the two types of nontax sources in terms of the mechanisms of incentivizing human behavior, and concludes with policy implications for researchers and practitioners.
\end{abstract}

\section{Introduction}

One of the major challenges that local governments face during economic hardship is fulfilling their financial responsibilities. The increasing demand for more services coupled with the worsening economy makes local revenue decisions "the fiercest policy battleground of state-local relations" (Krane, Ebdon, and Bartle 2004: 515). In fact, a marked change has been found in local revenue structure in recent years. With increasing frequency, local governments are seeking out alternative, nontax sources of local revenue - such as fees, licenses, user charges, fines, forfeitures, and other miscellaneous revenues - to bolster traditional revenue sources such as property taxes, sales taxes, and income taxes (Krane et al. 2004; Carroll and Stater 2009; Carroll and Johnson 2010; Gamkhar and Pickerill 2012). The revenue potential of these nontax sources becomes considerable and attractive for local governments, but scholarly attention to nontax revenue has been relatively thin (Blom-Hansen, Monkerud, and Sorensen 2006; exceptions include Krane et al. 2004; Hoene 2004; Bartle, Kriz, and Morozov 2011).

This study is an attempt to deepen our understanding of local revenue structure by examining the impact of the economy and intergovernmental fiscal relationship. Specifically, this article investigates why some localities rely more on alternative revenue sources than others, how a worsening economy affects reliance on nontax own-source revenue, and whether it is moderated by local dependence on intergovernmental transfers. Local governments in general operate in a highly complex environment where their performance is determined by various internal and external conditions (Da Cruz and Marques 2014). Yet local revenue structure is not only an outcome of economic, fiscal, and political 
context but also involves some sort of "strategic or self-interested behavior by local actors" (Bartle et al. 2011: 271; Bartle 1996; Hendrick 2013). Local officials try to find ways to cover the losses with compensating strategies such as issuing bonds, delaying and canceling payments, encouraging more businesses, and finding new sources of revenue rather than raising taxes (Cain and Mackenzie 2008; MacManus 1993).

This article focuses on the two types of nontax own-source revenue - fees/charges and fines/forfeitures - in terms of the mechanisms of incentivizing human behavior and solving public sector problems with market-based solutions and direct regulation (Stiglitz 2000). ${ }^{i}$ Among the various tools of government, local government officials including Board of Supervisors, county commissioners, and local chief financial officers (CFOs) may choose to specify monetary charges for certain activities and/or crack down on fraud as a way of securing the budget without more taxation.

The hypotheses are tested across the counties in California between 2000 and 2010. The time scope of the study within a specific state and county context may raise the generalizability issue. Yet the findings have broad implications on revenue structure of local governments, many of which have been impacted since the 2000s, when economic recessions became a new normal. The recession that began in 2001 and was regarded as the "worst fiscal crisis since the Depression” changed the state-local fiscal relationship significantly (Krane 2004; Hendrick 2013: 223). Moreover, externally imposed constraints and pressures such as Proposition 13 actually are not unique to California (Barbour 2007), and the state's overall fiscal patterns are not very different from states that are less constrained (Cain and Mackenzie 2008).

Data are drawn from various sources such as the Counties Annual Report, Bureau of Labor Statistics, RAND California, and California Elections Data Archive (CEDA). The following section describes local governments in California, reviews literature on fiscal federalism that provides a fiscal incentives perspective on local revenue structure, and discusses revenue potential of two types of nontax revenue. Hypotheses are developed in the next section, followed by the description of data and models. Next we present and discuss our results before concluding with policy implications for researchers and practitioners.

\section{Literature}

\section{$\underline{\text { Local Governments in California }}$}

Local governments in California provide an appealing context for exploring the research question of the study focusing on the incentives involved in local fiscal decisions. They spend relatively large amounts of money compared to counties in other states and have a wide variety of responsibilities via local demands as well as state mandates. ${ }^{\mathrm{ii}}$ As the role of county governments has been significantly expanded in recent years, it allows them a wide range of options in revenue decisions as well as in services or programs (Sokolow and Detwiler 2001; Benton 2002; Chapman 2003; Streib et al. 2007). Counties have statutory responsibility for collection and distribution of nontax revenue.

However, local autonomy in property taxation has been limited since the 1970s (Solokow 2000; Krane et al. 2004). In particular, Proposition 13 in 1978 forbade local officials from setting their own property tax rates in order to protect homeowners, which lead to a decrease in dependence on local property taxes while prompting local governments to seek out alternative sources of revenue (Carroll and Johnson 2010). It is mainly because elected officials in the interlocal competitions for residents, employment, and businesses may be reluctant to raise property tax rates as the unpopular measure creates political risks (Tiebout 1956; Peterson 1981; Krane et al. 2004). Since Proposition 13, the state-local fiscal conflicts in California have intensified and state-local antipathies have become more severe in times of economic strain (Neiman and Krimm (2009). Several attempts have been made to modify the state-local relationship and to limit the state's fiscal interference; however, they have not quite been successful (Danielson and Mejia 2011).

As local governments in California have experienced both an increase in state mandates and a decrease in taxable transactions and intergovernmental aid, local authorities have aimed to diversify their revenue structures in order to decrease reliance on property taxes and increase flexibility and stability. This has been especially evident since the early 2000s. County Legislature has limited control over nontax-related decisions mainly due to the formula-based system (Taylor 2016), while the Board of Supervisors impose/increase nontax, taxes and assessments as a county revenue authority. Other administrative entities in counties, such as Councils of Government and Special Districts, are responsible for the use of nontaxes and the services related to future needs. 


\section{Fiscal Federalism Under Pressure}

The study identifies a set of arguments in the literature on fiscal federalism so as to determine the extent to which factors affect reliance on alternative revenue sources. Theoretical discussion on fiscal federalism has evolved through the first and second generations. First-generation fiscal federalism focuses on the design of fiscal institutions for social welfare maximization by allowing local governments to provide local public goods that meet the demand of residents in their jurisdiction (Oates 2005, 2008). On the other hand, second-generation fiscal federalism centers on the fiscal incentives of political officials related to own-source revenue. The fiscal incentives approach allows us to consider other political goals by relaxing the strict assumption on revenue maximization (Weingast 2009), and provides significant implications for the design of intergovernmental transfer systems within a multi-level government setting.

The fiscal relationship with higher levels of government is essential to stabilize the local economy. As an important tool of fiscal federalism, intergovernmental transfers mitigate vertical and horizontal imbalances (Oates 2005, 2008) and generate incentives to foster local economic prosperity (Weingast 2009). More specifically, federal and state governments direct and coordinate public policy across the nation, facilitate local adjustment to fiscal shocks, and create positive effects on spending by improving efficiency, equity, and stability of the subnational government sector. A number of previous efforts have been made to identify the effect of shrinking intergovernmental transfers on local economies; however, the effects of these transfers in local government finance "are far less obvious" (Wildasin 2009: 1).

Public economics and fiscal illusion scholarship posits that a highly transfer-dependent local government may face weaker incentives for fiscal responsibility due to bailout expectations and moral hazard of local officials and politicians (e.g., Rodden 2006). Furthermore, the incentives for fiscal discipline can be undermined by politicians and upper-level government coalitions that are willing to use intergovernmental transfers as a strategic tool to maximise their interests (Rodden 2006). Thus, the intergovernmental fiscal relationship brings efficiency loss from the soft budget constraint, which distorts local behaviours based on the rescue expectations (Oates 2005, 2008; Kornai, Maskin, and Roland 2003).

On the other hand, a highly dependent locality is more likely to suffer from fiscal stress as intergovernmental revenue decreases. Shrinking transfers will result in immediate revenue reduction in local governments. Considering the vulnerability, local officials may have a dire need for developing alternative revenue sources during economic hardship (ACIR 1989). They may fear states will be reluctant to help them, considering the fiscal constraint and the mood of devolution from federal to state, and state to local (Johnston et al. 2000).

In recent years, local governments are under a new challenge in the form of fend-for-yourself federalism or bottomup federalism (Gamkar and Pickerill 2012). Fend-for-yourself federalism requires a more active role of local governments in revenue decisions as they are expected to address their issues without assistance from the upper governments and even refuse federal assistance to protest politics and policies imposed on them (Nicholson-Crotty 2012). Thus, localities with unstable revenues tend to increase reliance on nontax for services, fees and charges in particular (Cain and Mackenzie 2008). Collection of nontax revenue becomes less administratively costly due to technological development (Bartle et al. 2011). More so, public opinion favors user charges during hardship, although not without resistance (Downing 1992; Hendrick 2013).

\section{Alternative Revenue Sources}

Fiscal federalism literature argues that local governments are in a better position to rely on the benefit principle of taxation (Oates 2005, 2008). Among nontraditional alternative sources, user fees and charges imposed for a variety of services such as sewerage, transportation, and public utilities take up the largest share in the local revenue. There is a consensus that reliance on these sources will continue to grow. The ratio of fees and charges to own-source revenue of Los Angeles County ranged from 20.36 to 30.72 percent, amounting to 1.39 to 1.85 billion dollars between 2000 and 2010 ${ }^{\text {iii }}$

The primary purpose of levying fees and charges may not be to raise revenue. However, their potential as a new source of revenue with economy-enhancing effects has been discussed in several studies (Oates 2005, 2008; Jung and Bae 2011; Sun and Jung 2012). Local governments often look to their services as revenue sources to cover the costs of private activities and administrative operations (Bierhanzl and Downing 2004), although rigorous cost evaluations 
such as the balanced scorecard approach have been rarely used in public utilities (Guimarães et al. 2010). Other factors such as intergovernmental revenue (Johnston et al. 2000), tax and expenditure limitations (Mullins and Joyce 1996; Johnston et al. 2000), government structure (Benton 2002, 2003), and functional changes (Tannenwald 1990) may affect their choice of revenue source.

Fees and charges can be useful when it is possible to exclude non-users from those who benefit from the good or service. We would expect efficiency gains from financing with fees and charges because it discourages wasteful use of resources or services (Bierhanzl and Downing 2004); but it also engages inefficiencies or distortions from inaccurate pricing such as under-consumption of the relevant good or service (Stiglitz 2000; Hendrick 2013).

On the other hand, fines and forfeitures used as regulation and punitive monetary sanction have received little attention mainly due to their small share within the total revenue of local governments. Yet the offender-focused economic sanctions have been one of the most frequently used tools of punishment against minor crimes and offenses (Becker 1968). Mostly determined by trial courts, the nontax revenue level from criminal violations is relatively higher in California compared to other states; it accounts for one to fifteen percent (mostly less than five percent) of own-source revenue in California.

The advantage of imposing fines and forfeitures is related to economic benefits, both in terms of compensation to other members of society and as a warning to potential offenders. Fines and forfeitures can be flexible and do not use up social resources in implementing the punishment except for collection costs, and eventually they increase social welfare (Becker 1968). However, they are criticised as being unfair and failing to meet the goal of individualized justice, since they do not adversely affect those who can afford the price of punishment (Becker 1968). It is also worth noting that treating citizens as potential offenders to generate revenue may lead to unintended consequences by changing their behavior in the long run.

\section{Hypotheses}

Our key hypothesis is that a worsening economy increases reliance on nontax revenue, and the dependence on intergovernmental transfers moderates that impact. Control variables include three groups of factors set to capture local fiscal condition, political preference, and socioeconomic characteristics that reflect spending needs of county governments.

\section{Economic Hardship}

The economy is an essential part of local finance. It has often been argued that local officials have little control over the economy determined by external factors (Bahl 2004), and their fiscal choices may not be predictable and rely on heuristics and bounded rationality (Morgan and Pammer 1988; Nelson 2012). However, local officials have diverse coping strategies depending on economic conditions that sometimes create entrepreneurial solutions (Bartle 1996; Bartle et al. 2011; Cain and Mackenzie 2008; Levine 1978; Nelson 2012; Nelson and Svara 2015). Thus, the impact that economic recessions have on revenue varies across local governments.

Local governments under fiscal stress have few choices in revenue decisions - adjusting their fiscal decisions on expenditure, savings, and revenue (Bartle 1996; Gamkhar and Pickerill 2012; Nelson 2012; Wolman 1983). Cutting the existing level of expenditure could be a direct response from a locality under fiscal pressures. MacManus (1993) argues that localities are more inclined to reduce spending than to raise taxes as they expect less resistance from residents. Raising taxes becomes more difficult as constrained by state controls and competition with other local governments, in addition to tax and expenditure limitations (TELs) (Pagano and Johnston 2000). Neither cutting expenditures nor raising taxes, however, has been particularly viable or politically popular (Neiman and Krimm 2009). Local officials can borrow money via short-term loans (Clark 1994) or use stabilization funds (Bartle 1996; Marlowe 2005), but these are stopgap measures.

Another option is to find new sources of revenue. Local officials may consider broadening the tax base to increase revenue available to the government (Wolman 1983; Nelson 2012). However, localities under economic hardship have limited abilities to implement base-broadening measures that require considerations for the long-term impact on the economy and transitioning to a new tax report system. Accordingly, they may shift reliance to revenue sources that are less sensitive to economic conditions (Bartle et al. 2011). 


\section{H1: Reliance on nontax revenue will increase when the economy worsens.}

\section{Intergovernmental Revenue}

The largest share of county revenue comes from intergovernmental transfers. State intergovernmental revenue accounted for more than 30 percent of local revenue in the 2000s, and counties have some controls over the state general assistance based on a formula as well as matching (Chapman 2003; Hendrick 2013). Compared to the revenue from the state, the amount of federal government transfers is modest (Bartle et al. 2011). Yet federal transfers that can be distributed directly to local governments or passed indirectly through their state governments with strings attached, making them an important revenue source (Wildasin 2009; Bartle et al. 2011).

As discussed earlier, competing claims regarding the impact of transfer-dependence are supported by fiscal incentives in the literature. On the one hand, local governments with higher dependence on intergovernmental transfers are expected to be reluctant to make an effort to increase nontax reliance because they expect higher governments will help them during economic hardship. On the other hand, transfer-dependent localities can be more proactive to revenue policy to fend for themselves under severe economic hardship. This leads us to a two-tailed non-directional hypothesis on the effect of intergovernmental revenue $(H 2)$ and a conditional hypothesis $(H 3)$ that the effect of the economy on the reliance on nontax revenue will not be the same, given the variable dependence on intergovernmental transfers.

\section{H2: Reliance on nontax revenue will be positively (or negatively) associated with the dependence on intergovernmental transfers.}

H3: The effect of the economy on nontax revenue reliance will be positively (or negatively) moderated by the dependence on intergovernmental transfers.

\section{Fiscal Condition}

Nontax reliance will vary according to the fiscal condition of local governments. A number of previous efforts have been made to measure and monitor fiscal health, which generally refers to the government's ability meet its financial and service obligations (ACIR; Nollenberger 2003; Hendrick 2004). Various indicators include revenue diversification, flexibility, revenue-to expenditure ratio, debt per capita, bond ratings, liabilities, taxable value, and general fund expenditure (Hendrick 2004). This article uses property tax ratio as a measure of revenue diversification (ACIR 1989; Pagano and Johnston 2000), and fiscal slack as a measure of flexibility in the fiscal structure.

Local property tax is the most important single own-source tax under the discretion of local governments and has been regarded as less dependent on the economy compared to income tax and sales tax. ${ }^{\text {iv }}$ Local governments in California heavily rely on property taxes - although California's local autonomy in property taxation has been damaged since Proposition 13, meaning elected officials may be reluctant to raise property tax rates (Peterson 1981; Krane et al. 2004). Research shows that revenue diversification lowers tax effort (Hendrick 2002) and leads to stability in revenue structure (Carroll and Stater 2009); however, the effect is not always clear and depends on the types of services provided by local governments (Carroll and Johnson 2010; Mikesell 2014).

The level of fiscal slack represents the government's flexibility in managing bad fiscal conditions and buffering environmental shock and uncertainty. Scholarship on fiscal slack has been well developed in public finance literature although it is less known in the local government context (MacManus 1993; Hou 2004; Rose and Smith 2012; exceptions include Marlowe 2005 and Hendrick 2004, 2006). Slack resources set aside for various reasons such as budget stabilization, however, oftentimes trigger political pressures from taxpayers and other stakeholders (Rose and Smith 2011; Hendrick 2004, 2006; Hou 2004). Counties with more flexibility in fiscal structure are less likely to rely on nontax revenue.

\section{Political/Ideological Preference}

Politicians, regardless of party ideology, may not take a positive attitude toward revenue policy because it is unpopular with voters. This "taxation by inertia” is evident in political science research (Rose 1985). Studies suggest that politics and political bargaining among parties with different ideologies could be a significant factor in local revenue decisions (Blom-Hansen et al. 2006; Carroll and Stater 2009). Since California requires direct voter approval of taxing and 
spending activities (Cain and Mackenzie 2008), constituents' political preference is expected to affect reliance on nontax revenues. Supporters of liberal governments are believed to be more receptive to revenue-raising strategies through taxation, while advocates of conservative governments are reluctant to raise tax rates and favor tight fiscal policy (Blom-Hansen et al. 2006).

\section{Spending Needs and Local Characteristics}

Local governments will be less pressured to seek alternative sources or change revenue structure if they are able to meet their spending needs within the current fiscal situation. The factors included in the study are the level of income, demographic characteristics, and poverty rates. Level of income is a commonly used measure for tax base, and local governments with higher income are more inclined to pass revenue-enhancing strategies based on the user-based system (Cain and Mackenzie 2008). Since the current financial decisions have obligated future resources, increases in the productive population suggest increase in taxable capacity (Tannenwald and Cowan 1997; Bahl 2004). The percentage of productive age groups between 45 and 64 in the total county population is used as a proxy for the tax base and spending needs, following previous studies (e.g., Bahl 2004). County poverty rate is included as a proxy for the county fiscal needs for more services (Tannenwald and Cowan 1997; Hendrick 2004).

\section{Data Measures}

This study utilises a panel dataset including 57 counties across 11 years from 2000 to 2010. We exclude the city and county of San Francisco in the context of the study because of its unique status as the only consolidated city-county in California. The explanatory and control variables are lagged one year. All the finance data are inflation-adjusted for the year 2010 based on the CPI-U from Bureau of Labor Statistics information. ${ }^{\mathrm{v}}$

The dependent variable is measured in two ways to assess the impact of reliance on nontax revenue: (1) the ratio of nontax revenue to own-source revenue (\%), and (2) per capita amount of nontax revenue (\$). The ratio and the amount will not always necessarily correlate; the ratio could increase while the amount shrinks, and vice versa. The ratio variable is sensitive to changes in other resource categories but is most frequently used in public finance literature (Mikesell 2014; Jung and Bae 2011). The per capita variable is useful to compare individual shares but engages in some dangers in estimation as it can misrepresent the counties with a high percentage of non-residents (Hendrick 2002, 2004). We use the natural logarithm of the per capita measures to normalize the skewed distribution.

[Table 1]

The explanatory variable that accounts for the economy can be measured with several indicators, including jobs, unemployment rate, economic output such as GDP, and housing prices. We use two local-level indicators of the economy: county unemployment rate (\%) and housing prices (\$).

The counties' dependence on intergovernmental transfers is calculated by the ratio of the aggregate amount of revenue from the federal and state governments transfer to total revenue. ${ }^{\text {vi }}$ Although the characteristics of the federal and state transfers are different, the model includes the aggregated variable, given that the purpose of the study is to investigate the moderating effect of the transfer-dependence on local revenue structure. The alternative models allow us to identify the differential effects of the federal and state grants, but the strategy did not contribute to the explanatory power of the models and the results were not substantially affected by such alternative coding schemes.

The property tax ratio as a proxy for the degree of revenue diversity is measured by the percentage of property tax to own-source revenue of a county. Own-source revenue includes all tax revenues, such as property taxes, income taxes, sales taxes; and nontax revenues, such as fees, charges, fines, forfeitures, miscellaneous revenue, utility revenue; but excludes intergovernmental aid from federal, state, and other local governments (Mikesell 2014).

Originally discussed in organizational literature, fiscal slack was known to be difficult to measure and apply to the public sector (Hou 2004; Hendrick 2004). Several indicators used in previous studies include budget stabilization fund, unreserved fund balance, and discretionary spending, as well as the size of government. We use the unreserved fund balance available for appropriation as a primary source of fiscal slack and a rainy day fund during hard times 
(Hendrick 2004). It is measured by the sum of designated and undesignated portions of fund balances in governmental funds, including general funds as well as capital project, debt service, and special revenue funds. The variable is calculated as a percentage of total revenue.

The political preference of county residents is measured by the vote rates earned for the democratic Governor or gubernatorial candidate in general elections. The data is obtained from the California Elections Data Archive (CEDA) and California State Archives. Details on data, measures, and sources are described in Table 1.

\section{Result}

We developed empirical models to explore local revenue choices on (1) fees and charges, (2) fines and forfeitures, and (3) the sum of both. We estimate linear and interaction models for the reliance on nontax revenue along with separate models for each type of nontax revenue. The specification without interaction estimates the linear effects as suggested by $H 1$ and $H 2$ - by running the first regression.

$$
\text { NontaxRev }_{i t+1}=\alpha_{i t}+\beta_{2} I G R_{i t}+\gamma_{1} X_{i t}+\theta_{i}+\mu_{t}+\varepsilon_{i t}
$$

Panel data can be estimated using several different models according to the assumption of the characteristics of residuals. Based on the Hausman test and theoretical considerations, the fixed effects approach is preferred in the analysis. ${ }^{\text {vii }}$ Robust standard errors were clustered by county with year dummies. The endogeneity among the variables may or may not be overcome by lagging the variables one year. However, the correlation coefficients and variance inflation factors show no sign of severe problems. The estimation result holds up to a number of robustness checks, including the inclusion of variables with alternative measures and models. viii

The fixed effects estimation on the linear models for the ratio of nontax revenue reveals a significant positive impact of unemployment rate and a negative impact of average housing price, implying that reliance on nontax revenue increases when the economy worsens regardless of the nontax type or subcategory. Local government under pressure may be more inclined to fulfill their responsibilities by seeking alternative revenue sources as a compensation for tax losses due to a decrease in income tax (from higher unemployment rates) and property tax (from depreciating housing prices).

The impact of the economy on the revenue structure (H1) is supported by the significant increase in reliance on nontax revenue. However, we need a careful assessment of the impact because it could be a result of declining own-source revenue during economic downturns without efforts to collect more revenue from nontax sources. As shown in the per capita models in Table 3, the impact of the economy on per capita amount of nontax revenue was partly supported (Models 5 and 6). Per capita revenue from fines and forfeitures, in particular, does not appear to be associated with the economy variables in part because they are held by the justice system and the role of county officials is limited in this revenue category. However, the effect of economic conditions on the ratio and amount of nontax revenue seems not negated by declining own-source revenue.

\section{[Tables 2 and 3]}

Regarding the two-tailed hypotheses (H2), support for the positive relationship between reliance on nontax revenue and intergovernmental transfers is found in the ratio and per capita models with all of the nontax categories. The results suggest that counties are likely to raise more revenue from nontax sources when their revenue is more dependent on intergovernmental transfers. The reported result does not confirm whether the negative relationship does or does not exist; however, the specification and interpretation of the interaction model provide us with a few pieces of the puzzle. The second specification with an interaction term estimates the moderating effects-as suggested by H3-by running the second regression.

$$
\text { NontaxRev }_{i t+1}=a_{i t}+\beta_{1} \text { Economy }_{i t}+\beta_{2} I G R_{i t}+\beta_{3} \text { Economy } I G R_{i t}+\gamma_{1} X_{i t}+\theta_{i}+\mu_{t}+\varepsilon_{i t}
$$

, where NontaxRev is as defined above, Economy measured by unemployment rates or average housing prices, $X_{i t}$ are control variables, $\theta_{i}$ are county fixed effects, $\mu t$ are year fixed effects, and $\varepsilon_{i t}$ is an error term. Table 4 provides the estimation results of the fixed effects models with an interaction. 
[Table 4]

In the ratio models of nontax revenue, the interaction variable for county unemployment rate and intergovernmental transfers was positively significant, in addition to the variables that were significant in the linear fixed effects models. Although the inclusion of interaction terms requires that the coefficient be interpreted carefully, this suggests that the effect of the economy on nontax revenue will vary across counties with different levels of dependence on intergovernmental transfers. We can gain a better understanding of the moderating effect of intergovernmental transfers by being sensitive to changes in the marginal effect of the variable. Figure 1 presents how the marginal effect of county unemployment rates changes with the revenue dependence on intergovernmental transfers.

The solid line indicates the marginal effect of unemployment rates on nontax reliance, while the dashed line shows the $99 \%$ confidence interval around the solid line. The upper and lower boundaries of the confidence interval allow us to determine the range within which the independent variable has a statistically significant effect on the dependent variable. County unemployment rate has a statistically significant effect on nontax reliance as both bounds are above (or below) the zero line (for details, Brambor et al. 2006). Any particular point on the solid line is $\frac{\text { DNontaxRev }}{\text { dUnemp }}=\beta_{1}+$ $\beta_{3} I G R$.

[Figures 1 and 2]

Figure 1 shows the marginal effect of unemployment rates changes from negative to positive when county dependence on intergovernmental revenue increases. When counties' dependence on transfers is below 30 percent, the unemployment rate has a reductive effect on nontax reliance. In other words, if a county has less than 30 percent of transfers to total revenue, county officials are less likely to develop alternative revenue sources to meet their budget needs as soft budget constraint literature anticipates, but this negative marginal effect decreases as transfer-dependence increases. Once the transfer-dependence is over 58.2 percent (Mean=54.68 percent), county unemployment rate has a positive effect on nontax revenue, as we hypothesized. The positive effect increases as counties become more dependent on transfers. This is in line with the implication of fend-for-yourself or bottom-up federalism. Likewise, the second interaction variable for housing price and intergovernmental transfers was significant at the $95 \%$ level (Figure 2). The marginal effect of housing price was negative when county dependence on intergovernmental transfers is below 51.0 percent.

Counties with a higher property tax ratio in their revenue structure, i.e., with less diversified revenue structure, are less likely to raise revenue from nontax sources. Instead, the reliance on fines/forfeitures depends on slack resources that county governments accumulated. The finding suggests that counties with slack resources are more likely to increase revenues from fines/forfeitures, while the same variable was not significant in the fees/charges models. There are two possible interpretations here. One is that the data are simply insufficient to reveal the relationship in county governments; for example, the strategy to build up higher fund balances may not be effective enough to buffer the severe shortfalls that we have been experiencing in recent years (Bernanke 2011). The other, more weighty possibility is that counties with sound fiscal condition are less vulnerable to external shocks affecting revenue decisions, allowing them more discretion and capacity to implement economic sanctions.

The effect of the political preference of county residents in the per capita models was positively significant, implying that Democratic counties are more likely to rely on nontax revenue. However, the vote share is rather a coarse measure as the gubernatorial elections are held every four years and its impact was not evident in the ratio model. This supports the assertion that local decisions on financial management are more closely related to the existing financial structure than to the political preferences or demands of residents (Peterson 1981). The coefficient for county median income was marginally significant, implying that more affluent counties are less likely to rely on punitive measures as a way of raising revenue. The positive significance of productive population was found at the margin in the per capita models. 


\section{Conclusion}

This article is an effort to provide theoretical and practical implications by exploring how local governments adjust their revenue structure under fiscal relations with higher levels of government. Nontax revenue becomes more appealing to local governments under economic hardship. It will continue to be so, given that localities are more involved with publicly produced private services, and local economy tends to bounce back slowly and may not be controllable by localities in the short term.

In addition, nontax sources merit more attention from researchers and practitioners not just for their revenue potential, but also for equity considerations in democratic settings (Peterson 1981; Johnston et al. 2000; Sun and Jung 2012). Levying fees and charges can be fair in that the beneficiaries pay the burden for the service received, and it has the distributional advantage of reducing cross-subsidization between localities (Tannenwald 1990; Downing 1992). However, fees and charges in particular have a potentially regressive nature in that they do not take into account the user's ability to pay (Bahl 2004), and are levied mostly for services that users cannot decline. Tannenwald (1990) argues that user-charge financing for mixed or collective goods/services can be neither efficient nor equitable. In order to hold county officials accountable to use of nontax revenue, it is important to collect and distribute nontax revenue based on need, not on formula (Taylor 2016).

This study also calls attention to the two types of nontax sources associated with different incentive mechanisms based on the benefit and punitive principles. While our models did not include specific variables for two nontax categories, it sets the stage for the development of more differentiated models in the future. What we found is that the two revenue categories share common ground as potential revenue sources: the choice for scrutiny may be related to economic efficiency as much as it is related to sanction or coercion itself.

There are several aspects of the study that need further attention. First, appropriate caution should be exercised in generalizing the findings of the study. Although the study controls by design for the time-invariant institutional factors, i.e., government structure, future efforts would do well to focus on the institutional factors on local revenue choices to make inferences. However, we need to be attentive to the potential danger of overestimating the effect of institutional changes by including indicator variables (Cain and Mackenzie 2008).

Second, since we have used the total amount of nontax revenue, we could not tell the difference between the increase caused by raising rates and that caused by exploitation of new sources. This excludes the possibility that changes in the base could be a reason for changes in these sources over time, such as fees based on property development. Nevertheless, merging the two possibilities does not raise serious problems given the purpose of this study. Also worth noting is that the empirical models do not directly tackle the issue of inter-fund transfers. The inter-fund transfers between non-general funds to general funds in revenues and expenses are quite common but not without legal procedures, i.e., approval of the county board of supervisors. Transaction costs involved in inter-fund transfers may affect the revenue potential of nontax sources of local governments.

Finally, the potential and feasibility of nontax revenues depends on the functions and nature of the services county governments provide that may or may not be controlled by service demands. Previous studies found that service provision and expenditure mix may affect local revenue structure (Tannenwald 1990; Jung and Bae 2010). However, the data was not available and this study tends toward a more comprehensive look at local revenue structure focused on the factors that affect nontax reliance, regardless of where and how the nontax revenues are collected. Another area of focus for future research is the revenue potential according to the types of functions performed by localities. 
Table 1 Data and Measures

\begin{tabular}{|c|c|c|}
\hline Variables & Data and Measures & Source \\
\hline Dependent variables & $\begin{array}{l}\text { The ratio of nontax revenue out of own-source } \\
\text { revenue (\%) } \\
\text { Per capita amount of nontax revenue (\$) (Log- } \\
\text { transformed) }\end{array}$ & $\begin{array}{l}\text { RAND California Statistics } \\
\text { http://www.ca.rand.org } \\
\text { Counties Annual report } \\
\text { http://www.sco.ca.gov }\end{array}$ \\
\hline \multicolumn{3}{|c|}{ Explanatory and control variables } \\
\hline Unemployment rate (L) & County unemployment rate (\%) & $\begin{array}{l}\text { Bureau of Labor Statistics } \\
\text { http://www.bls.gov }\end{array}$ \\
\hline Average housing price (L) & $\begin{array}{l}\text { Average sale price per square feet for all } \\
\text { residential housing (\$) }\end{array}$ & $\begin{array}{l}\text { California Association of } \\
\text { Realtors } \\
\text { http://www.car.org }\end{array}$ \\
\hline \multirow[t]{2}{*}{$\begin{array}{l}\text { Intergovernmental transfers } \\
\text { (L) }\end{array}$} & $\begin{array}{l}\text { The ratio of intergovernmental revenue out of total } \\
\text { revenue (\%) }\end{array}$ & RAND California \\
\hline & $\begin{array}{l}\text { Per capita intergovernmental revenue (federal and } \\
\text { state) (\$) }\end{array}$ & Counties Annual Report \\
\hline Property tax ratio $(\mathrm{L})$ & $\begin{array}{l}\text { The ratio of property tax revenue out of own- } \\
\text { source revenue (\%) }\end{array}$ & \\
\hline Fiscal slack (L) & $\begin{array}{l}\text { The ratio of unreserved fund balance (designated } \\
\text { and undesignated) to total revenue (\%) } \\
\text { Per capita unreserved fund balance (\$) }\end{array}$ & \\
\hline Ideological preference (L) & $\begin{array}{l}\text { The percentage of people who voted for the } \\
\text { Democratic candidate in the gubernatorial } \\
\text { elections in 1998, 2002, 2006, } 2010 \text { (\%) }\end{array}$ & $\begin{array}{l}\text { California Elections Data } \\
\text { Archive (CEDA) }\end{array}$ \\
\hline $\begin{array}{l}\text { County residents’ income } \\
\text { level (L) }\end{array}$ & Median income (\$) & $\begin{array}{l}\text { California State Archives } \\
\text { http://www.sos.ca.gov }\end{array}$ \\
\hline Productive population (L) & $\begin{array}{l}\text { The percentage of people in the age group of } 45-64 \\
\text { (\%) }\end{array}$ & $\begin{array}{l}\text { U.S. Census Bureau } \\
\text { http://www.census.gov }\end{array}$ \\
\hline Poverty rate (L) & Poverty rate (\%) & \\
\hline
\end{tabular}


Table 2 The ratio of nontax revenue (\%)

\begin{tabular}{|c|c|c|c|c|c|c|}
\hline \multirow{3}{*}{$\begin{array}{l}\text { Models } \\
\text { DV } \\
\text { County unemployment rate } \\
\text { (L) }\end{array}$} & 1 & 2 & 3 & 4 & 5 & 6 \\
\hline & \multicolumn{2}{|c|}{ \% Fees and charges (A) } & \multicolumn{2}{|c|}{ \% Fines and forfeitures (B) } & \multicolumn{2}{|c|}{ \% Nontax revenue $(\mathrm{A}+\mathrm{B})$} \\
\hline & $\begin{array}{l}.2391 * * \\
(.0998)\end{array}$ & - & $\begin{array}{l}.0764 * \\
(.0432)\end{array}$ & - & $\begin{array}{r}.3155^{* * *} \\
(.1174)\end{array}$ & - \\
\hline Average housing price (L) & - & $\begin{array}{r}-.0119 * * * \\
(.0037)\end{array}$ & - & $\begin{array}{r}-.0029 * * \\
(.0012)\end{array}$ & - & $\begin{array}{r}-.0148 * * * \\
(.0047)\end{array}$ \\
\hline $\begin{array}{l}\text { \% Intergovernmental revenue } \\
\text { (L) }\end{array}$ & $\begin{array}{r}.2911^{* * *} \\
(.0496)\end{array}$ & $\begin{array}{r}.2717 * * * \\
(.0774)\end{array}$ & $\begin{array}{r}.0519 * * \\
(.0218)\end{array}$ & $\begin{array}{r}.0449 * * \\
(.0186)\end{array}$ & $\begin{array}{r}.3430 * * * \\
(.0560)\end{array}$ & $\begin{array}{r}.3167 * * * \\
(.0871)\end{array}$ \\
\hline Property tax ratio (L) & $\begin{array}{r}-.1485 * * \\
(.0630)\end{array}$ & $\begin{array}{r}-.2007 * * * \\
(.0626)\end{array}$ & $\begin{array}{r}-.0239 \\
(.0227)\end{array}$ & $\begin{array}{r}-.0318 * \\
(.0176)\end{array}$ & $\begin{array}{r}-.1725 * * \\
(.0696)\end{array}$ & $\begin{array}{r}-.2326 * * * \\
(.0706)\end{array}$ \\
\hline Fiscal slack (L) & $\begin{array}{r}.0167 \\
(.0204)\end{array}$ & $\begin{array}{r}-.0033 \\
(.0254)\end{array}$ & $\begin{array}{r}.0148 * * \\
(.0063)\end{array}$ & $\begin{array}{r}.0076 \\
(.0091)\end{array}$ & $\begin{array}{r}.0315 \\
(.0214)\end{array}$ & $\begin{array}{r}.0043 \\
(.0289)\end{array}$ \\
\hline Democratic vote shares (L) & $\begin{array}{r}.1053 \\
(.0600)\end{array}$ & $\begin{array}{r}.0465 \\
(.0595)\end{array}$ & $\begin{array}{r}.0102 \\
(.0199)\end{array}$ & $\begin{array}{r}-.0211 \\
(.0203)\end{array}$ & $\begin{array}{c}.1155^{*} \\
(.0688)\end{array}$ & $\begin{array}{r}.0254 \\
(.0619)\end{array}$ \\
\hline County median income (L) & $\begin{array}{r}.0000 \\
(.0000)\end{array}$ & $\begin{array}{r}-.0000 \\
(.0000)\end{array}$ & $\begin{array}{c}-.0000 * \\
(.0000)\end{array}$ & $\begin{array}{c}-.0000 * \\
(.0000)\end{array}$ & $\begin{array}{r}-.0000 \\
(.0000)\end{array}$ & $\begin{array}{r}-.0000 \\
(.0000)\end{array}$ \\
\hline Productive population (L) & $\begin{array}{r}-.0774 \\
(.4378)\end{array}$ & $\begin{array}{r}.2530 \\
(.6092)\end{array}$ & $\begin{array}{r}-.1925 \\
(.1639)\end{array}$ & $\begin{array}{r}-.1783 \\
(.1266)\end{array}$ & $\begin{array}{c}-.2699 \\
(.4419)\end{array}$ & $\begin{array}{r}.0747 \\
(.6629)\end{array}$ \\
\hline Poverty rates (L) & $\begin{array}{r}.3059 \\
(.2048)\end{array}$ & $\begin{array}{r}.4059 * * \\
(.1800)\end{array}$ & $\begin{array}{r}.0145 \\
(.0624)\end{array}$ & $\begin{array}{r}.0303 \\
(.0462)\end{array}$ & $\begin{array}{r}.3204 \\
(.2369)\end{array}$ & $\begin{array}{r}.4362 * * \\
(.1989)\end{array}$ \\
\hline Constant & $\begin{array}{r}-3015 \\
(12.655)\end{array}$ & $\begin{array}{r}1.8832 \\
(18.755)\end{array}$ & $\begin{array}{r}8.298 \\
(5.443)\end{array}$ & $\begin{array}{r}11.085 * * \\
(4.292)\end{array}$ & $\begin{array}{r}8.096 \\
(14.099)\end{array}$ & $\begin{array}{r}12.968 \\
(20.888)\end{array}$ \\
\hline Number of obs & 569 & 408 & 569 & 408 & 569 & 408 \\
\hline Number of groups & 57 & 53 & 57 & 53 & 57 & 53 \\
\hline R-sq (within) & .3263 & .2838 & .2148 & .1832 & .3743 & .3177 \\
\hline R-sq (overall) & .1305 & .0157 & .1052 & .0729 & .1653 & .0406 \\
\hline$F(8,56) / F(8,52)$ & 26.93 & 15.20 & 10.35 & 5.43 & 34.36 & 18.29 \\
\hline Prob $>$ F & .0000 & .0000 & .0000 & .0001 & .0000 & .0000 \\
\hline
\end{tabular}

Note 1 : *** $\mathrm{p}<0.01,{ }^{* *} \mathrm{p}<0.05,{ }^{*} \mathrm{p}<0.1$; (L) refers to variables that lagged one year.

Note 2: Standard errors noted in parentheses are adjusted for clusters in county (57 clusters for Models 1, 3, 5; 53 for Models 2, 4, 6). 
Table 3 Per Capita Nontax Revenue (\$) (Log-Transformed)

\begin{tabular}{|c|c|c|c|c|c|c|}
\hline \multirow{2}{*}{$\begin{array}{l}\text { Models } \\
\text { DV }\end{array}$} & 1 & 2 & 3 & 4 & 5 & 6 \\
\hline & \multicolumn{2}{|c|}{$\$$ Fees and charges (A) } & \multicolumn{2}{|c|}{ \$ Fines and forfeitures (B) } & \multicolumn{2}{|c|}{$\$$ Nontax revenue $(\mathrm{A}+\mathrm{B})$} \\
\hline County unemployment rate (L) & $\begin{array}{r}-.0120^{* *} \\
(2.852)\end{array}$ & - & $\begin{array}{r}.0024 \\
(.0080)\end{array}$ & - & $\begin{array}{r}.0077 \\
(.0064)\end{array}$ & - \\
\hline Average housing price (L) & - & $(.0001)$ & - & $\begin{array}{r}.0001 \\
(.0002)\end{array}$ & - & $\begin{array}{r}-.0005^{* *} \\
(.0002)\end{array}$ \\
\hline $\begin{array}{l}\text { PC Intergovernmental } \\
\text { revenue }(\mathrm{L})\end{array}$ & $\begin{array}{r}.0014^{* * *} \\
(.0001)\end{array}$ & $\begin{array}{r}.0000 * * \\
(.0000)\end{array}$ & $\begin{array}{r}.0000 * * * \\
(.0000)\end{array}$ & $\begin{array}{l}.0000^{*} \\
(.0000)\end{array}$ & $\begin{array}{r}.0000^{* * * *} \\
(.0000)\end{array}$ & $\begin{array}{r}.0000 * * \\
(.0000)\end{array}$ \\
\hline Property tax ratio (L) & $\begin{array}{r}-.0013 \\
(.0022)\end{array}$ & $\begin{array}{r}-.0023 \\
(.0019)\end{array}$ & $\begin{array}{r}-.0040 \\
(.0033)\end{array}$ & $\begin{array}{l}-.0035 \\
(.0029)\end{array}$ & $\begin{array}{r}.0027 \\
(.0035)\end{array}$ & $\begin{array}{r}.0015 \\
(.0037)\end{array}$ \\
\hline Fiscal slack (L) & $\begin{array}{r}-.0007 \\
(.0009)\end{array}$ & $\begin{array}{r}.0003 \\
(.0012)\end{array}$ & $\begin{array}{r}.0006 \\
(.0013)\end{array}$ & $\begin{array}{r}-.0002 \\
(.0002)\end{array}$ & $\begin{array}{r}.0012 \\
(.0008)\end{array}$ & $\begin{array}{r}.0005 \\
(.0015)\end{array}$ \\
\hline Democratic vote shares (L) & $\begin{array}{r}-.0022 \\
(.0029)\end{array}$ & $\begin{array}{r}.0026 \\
(.0036)\end{array}$ & $\begin{array}{r}-.0054 \\
(.0038)\end{array}$ & $\begin{array}{r}-.0032 \\
(.0043)\end{array}$ & $\begin{array}{r}.0125^{* * * *} \\
(.0041)\end{array}$ & $\begin{array}{r}.0129 * * \\
(.0050)\end{array}$ \\
\hline County median income $(\mathrm{L})$ & $\begin{array}{r}.0000 * * * \\
(.0000)\end{array}$ & $\begin{array}{r}.0000 * * \\
(.0000)\end{array}$ & $\begin{array}{r}.0000 \\
(.0000)\end{array}$ & $\begin{array}{r}-.0000 \\
(.0000)\end{array}$ & $\begin{array}{r}.0000 \\
(.0000)\end{array}$ & $\begin{array}{r}-.0000 \\
(.0000)\end{array}$ \\
\hline Productive population (L) & $\begin{array}{r}.0287 \\
(.0237)\end{array}$ & $\begin{array}{r}.0409 \\
(.0252)\end{array}$ & $\begin{array}{r}.0139 \\
(.0244)\end{array}$ & $\begin{array}{c}.0232 * \\
(.0150)\end{array}$ & $\begin{array}{r}-.0459 * \\
(.0260)\end{array}$ & $\begin{array}{r}-.0482 * \\
(.0283)\end{array}$ \\
\hline Poverty rates (L) & $\begin{array}{r}.0021 \\
(.0065)\end{array}$ & $\begin{array}{c}-.0008 \\
(.0068)\end{array}$ & $\begin{array}{r}-.0151 \\
(.0097)\end{array}$ & $\begin{array}{r}-.0067 \\
(.0107)\end{array}$ & $\begin{array}{r}.0039 \\
(.0088)\end{array}$ & $\begin{array}{r}.0067 \\
(.0076)\end{array}$ \\
\hline Constant & $\begin{array}{r}3.608 * * * \\
(.5693)\end{array}$ & $\begin{array}{r}3.359 * * * \\
(.6542)\end{array}$ & $\begin{array}{r}3.362 * * * \\
(.7320)\end{array}$ & $\begin{array}{r}3.268 \\
(.4883)\end{array}$ & $\begin{array}{r}-4.108 \\
(.7209)\end{array}$ & $\begin{array}{r}-3.678 * * * \\
(.8175)\end{array}$ \\
\hline Number of obs & 569 & 408 & 569 & 408 & 569 & 408 \\
\hline Number of groups & 57 & 53 & 57 & 53 & 57 & 53 \\
\hline $\begin{array}{l}\text { R-sq (within) R-sq } \\
\text { (overall) }\end{array}$ & $\begin{array}{l}.2337 \\
.3251\end{array}$ & $\begin{array}{l}.1442 \\
.3313\end{array}$ & $\begin{array}{l}.0668 \\
.2467\end{array}$ & $\begin{array}{l}.0275 \\
.3811\end{array}$ & $\begin{array}{l}.3579 \\
.0058\end{array}$ & $\begin{array}{l}.2581 \\
.0078\end{array}$ \\
\hline$F(8,56)$ & 17.48 & 4.06 & 3.69 & 3.43 & 27.86 & 13.45 \\
\hline Prob $>$ F & .0000 & .0008 & .0016 & .0031 & .0000 & .0000 \\
\hline
\end{tabular}


Table 4 Interaction Models

\begin{tabular}{|c|c|c|c|c|}
\hline $\begin{array}{l}\text { Models } \\
\text { DV }\end{array}$ & \multicolumn{2}{|c|}{ \% Nontax revenue } & \multicolumn{2}{|c|}{$\begin{array}{l}\text { \$ Nontax revenue } \\
\text { (Log-transformed) }\end{array}$} \\
\hline $\begin{array}{l}\text { County unemployment rate } \\
\text { (L) }\end{array}$ & $\begin{array}{r}-.9880 * * * \\
(.1813)\end{array}$ & - & $\begin{array}{r}-.0123 * * * \\
(.0043)\end{array}$ & - \\
\hline Average housing price (L) & - & $\begin{array}{r}-.0232 * * * \\
(.0070)\end{array}$ & - & $\begin{array}{r}.0001^{* *} \\
(.0000)\end{array}$ \\
\hline $\begin{array}{l}\text { Intergovernmental revenue } \\
(\% \text { or } \$)(\mathrm{L})\end{array}$ & $\begin{array}{r}.3205^{* * *} \\
(.0521)\end{array}$ & $\begin{array}{r}.2742 * * * \\
(.0941)\end{array}$ & $\begin{array}{r}.0000 * * \\
(.0000)\end{array}$ & $\begin{array}{r}.0000^{* * * *} \\
(.0000)\end{array}$ \\
\hline $\begin{array}{l}\text { Interaction (unemp } \times \text { IGR or } \\
\text { pcIGR) }(L)\end{array}$ & $\begin{array}{r}.0218 * * * \\
(.0027)\end{array}$ & - & $\begin{array}{r}.0000 \\
(.0000)\end{array}$ & - \\
\hline $\begin{array}{l}\text { Interaction (housing } \times \text { IGR } \\
\text { or pcIGR) }(L)\end{array}$ & - & $\begin{array}{r}.0003 * * \\
(.0001)\end{array}$ & - & $\begin{array}{r}.0000 \\
(.0000)\end{array}$ \\
\hline Property tax ratio (L) & $\begin{array}{r}-.2623^{* * * *} \\
(.0629)\end{array}$ & $\begin{array}{r}-.1848 * * \\
(.0784)\end{array}$ & $\begin{array}{l}-.0020 \\
(.0020)\end{array}$ & $\begin{array}{l}-.0021 \\
(.0017)\end{array}$ \\
\hline Fiscal slack (L) & $\begin{array}{r}.0168 \\
(.0187)\end{array}$ & $\begin{array}{r}-.0025 \\
(.0280)\end{array}$ & $\begin{array}{r}-.0004 \\
(.0007)\end{array}$ & $\begin{array}{c}-.0005 \\
(.0009)\end{array}$ \\
\hline Democratic vote shares (L) & $\begin{array}{r}.0548 \\
(.0705)\end{array}$ & $\begin{array}{r}-.0694 \\
(.0641)\end{array}$ & $\begin{array}{l}-.0024 \\
(.0024)\end{array}$ & $\begin{array}{c}-.0008 \\
(.0026)\end{array}$ \\
\hline County median income (L) & $\begin{array}{c}-.0001 * \\
(.0000)\end{array}$ & $\begin{array}{r}-.0000 \\
(.0000)\end{array}$ & $\begin{array}{r}.0000 * * \\
(.0000)\end{array}$ & $\begin{array}{c}.0000^{*} \\
(.0000)\end{array}$ \\
\hline Productive population (L) & $\begin{array}{r}-.4867 \\
(.4524)\end{array}$ & $\begin{array}{c}-.0234 \\
(.6772)\end{array}$ & $\begin{array}{r}.0252 \\
(.0202)\end{array}$ & $\begin{array}{r}.0232 \\
(.0182)\end{array}$ \\
\hline Poverty rates (L) & $\begin{array}{r}.1996 \\
(.2297)\end{array}$ & $\begin{array}{r}.4570 * * \\
(.2105)\end{array}$ & $\begin{array}{c}-.0004 \\
(.0057)\end{array}$ & $\begin{array}{r}.0007 \\
(.0056)\end{array}$ \\
\hline Constant & $\begin{array}{r}11.629 \\
(13.560)\end{array}$ & $\begin{array}{r}19.645 \\
(21.817)\end{array}$ & $\begin{array}{r}4.142 * * * \\
\quad(.5414)\end{array}$ & $\begin{array}{r}4.234^{* * * *} \\
(.4997)\end{array}$ \\
\hline Number of obs & 568 & 400 & 568 & 400 \\
\hline Number of groups & 57 & 52 & 57 & 52 \\
\hline R-sq (within) & .4634 & .3462 & .2589 & .1563 \\
\hline R-sq (overall) & .2626 & .0509 & .3512 & .4952 \\
\hline$F(9,56) / F(9,51)$ & 34.72 & 17.67 & 35.58 & 15.95 \\
\hline Prob $>$ F & .0000 & .0000 & .0000 & .0000 \\
\hline
\end{tabular}


Figure 1 Marginal effect of unemployment rate on \% nontax revenue

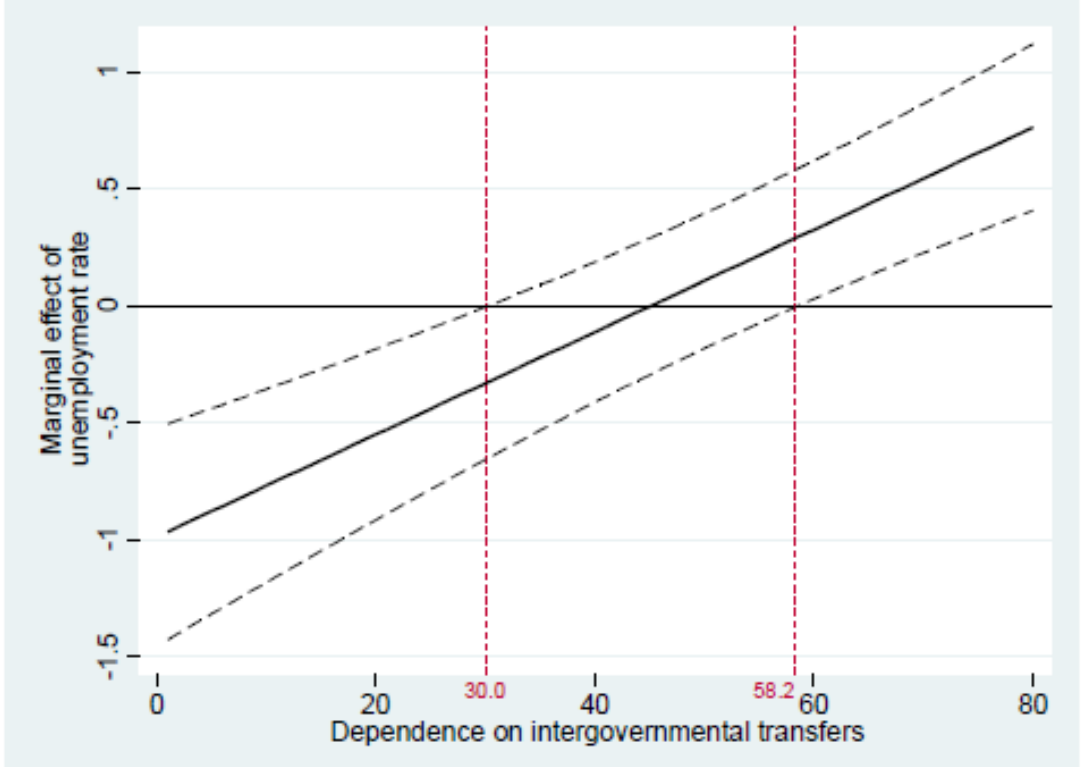

Note: The dashed line shows the 99\% confidence intervals around the solid line.

Figure 2 Marginal effect of average housing price on \% ontax revenue

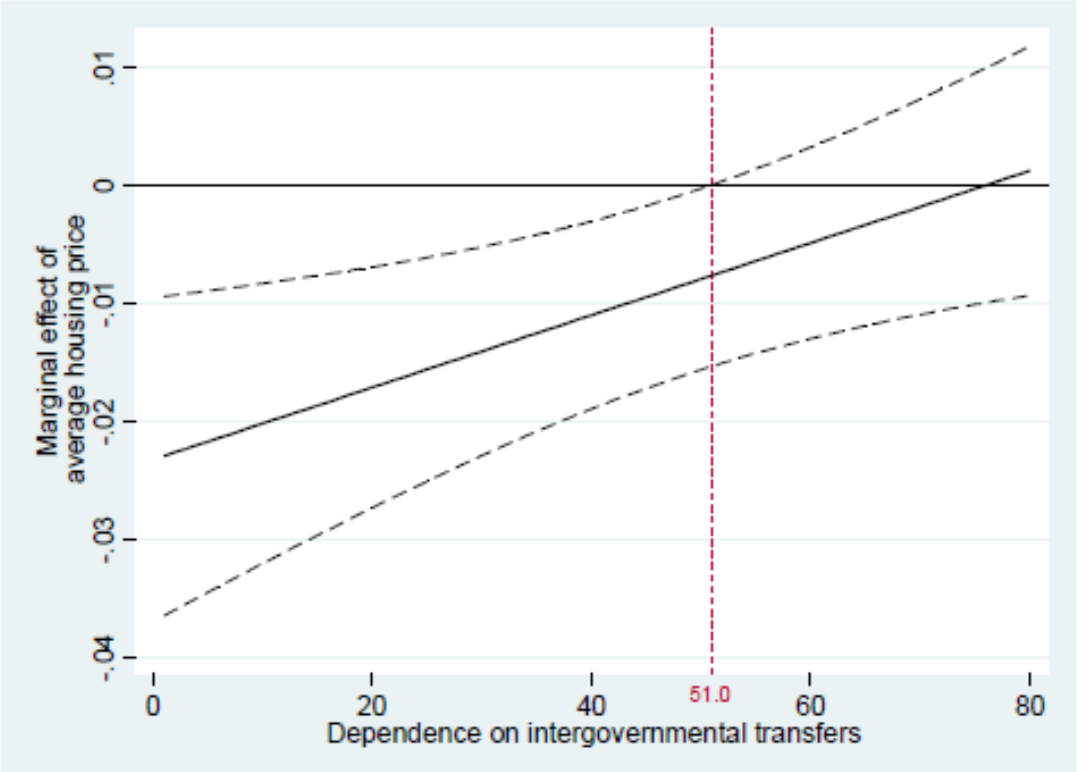

Note: The dashed line shows the 95\% confidence intervals around the solid line. 


\section{References}

Bahl, R. W. Jr. (2004). “Local Government Expenditures and Revenues.” In Management Policies in Local Government Finance. Aronson and Schwartz, ICMA. $5^{\text {th }}$ Edition.

Bartle, J. R. (1996). “Coping with Cutbacks: City Response to Aid Cuts in New York State.” State and Local Government Review 28(1): 38-48.

Bartle, J. R., K. A. Kriz, and B. Morozov. (2011). “Local Government Revenue Structure: Trends and Challenges.” Journal of Public Budgeting, Accounting \& Financial Management 23(2): 268-287.

Becker, G. (1968). “Crime and Punishment: An Economic Approach.” Journal of Political Economy 76(2): 169217.

Benton, E. J. (2002). “County Service Delivery: Does Government Structure Matter?” PAR 62(4): 471-79.

Benton, E. J. (2003). “County Government Structure and County Revenue Policy: What's the Connection?” State and Local Government Review 35(2):78-89.

Bierhanzl, E. J. and P. B. Downing. (2004). “User Charges and Special Districts.” In Management Policies in Local Government Finance. Aronson and Schwartz, ICMA. $5^{\text {th }}$ Edition.

Blom-Hansen, J., L. C. Monkerud, and R. Sorensen. (2006). "Do Parties Matter for Local Revenue Policies? A Comparison of Denmark and Norway.” European Journal of Political Research 45(3): 445-465.

Brambor, T.; W. R. Clark, M. Golder. (2006). "Understanding Interaction Models: Improving Empirical Analyses.” Political Analysis 14(1): 63-82.

Cain, B. E. and G. A. Mackenzie (2008). “Are California’s Fiscal Constraints Institutional or Political?” Public Policy Institute of California.

Carroll, D. A. and T. Johnson (2010). “Examining Small Town Revenues: To What Extent Are They Diversified?” Public Administration Review 70(2): 223-236.

Carroll, D. A. and K. J. Stater (2009). "Revenue Diversification in Nonprofit Organizations: Does it Lead to Financial Stability?” JPART 19(4): 947-966.

Chapman, J. I. (2003). “Local Government Autonomy and Fiscal Stress: The Case of California Counties.” State and Local Government Review 35(1): 15-25.

Da Cruz, N. F. and R. C. Marques. (2014). "Revisiting the Determinants of Local Government Performance.” OMEGA 44: 91-103.

Danielson, C. and M. C. Mejia. (2011). “The State-Local Fiscal Relationship in California” in Just the Facts. Public Policy Institute of California. Retrieved on Nov 13, 2013.

Downing, P. B. (1992). “The Revenue Potential of User Charges in Municipal Finance.” Public Finance Review 20(4): 512-527.

Gamkhar, S. and J. M. Pickerill. (2012). "The State of American Federalism 2012-2012: A fend for yourself and activist form of bottom-up federalism.” Publius 42(3): 357-386.

Guimarães, B., P. Simões, R. C. Marques. (2010). “Does Performance Evaluation Help Public Managers? A Balanced Scorecard Approach in urban waste services.” Journal of Environmental Management 91(12): 2632-38.

Hendrick, R. (2002). “Revenue Diversification: Fiscal Illusion or Flexible Financial Management.” Public Budgeting \& Finance 22(4): 52-72.

Hendrick, R. (2004). “Assessing and Measuring the Fiscal Health of Local Government: Focus on Chicago Suburban Municipalities.” Urban Affairs Review 40(1): 78-114.

Hendrick, R. (2006). “The Role of Slack in Local Government Finances.” Public Budgeting \& Finance 26(1): 1446.

Hendrick, R. (2013). “Nontax Revenue.” in Management Policies in Local Government Finance. An ICMA Green Book. $6^{\text {th }}$ Edition. Bartle, Hildreth, and Malowe. Ch. 10: 219-251.

Hoene, C. (2004). "Fiscal Structure and the Post-Proposition 13 Fiscal Regime in California Cities.” Public Budgeting \& Finance 24(4): 51-72.

Hou, Y. (2004). "Budget Stabilization Fund: Structural Features of the Enabling Legislation and Balance Levels.” Public Budgeting \& Finance 24(3): 38-64.

Johnston, J. M., M. A. Pagano, and P. A. Russo Jr. (2000). "State Limits and State Aid: An Exploratory Analysis of County Revenue Structure.” State and Local Government Review 32(2): 86-97.

Jung, C. and S. Bae. (2010). "Changing Revenue and Expenditure Structure and the Reliance on User Charges and Fees in American Counties, 1972-2002.” ARPA 41(1): 92-110.

Kornai, J., E. Maskin, and G. Roland. (2003). “Understanding the Soft Budget Constraint.” Journal of Economic Literature 41(4): 1095-1136. 
Krane, D., C. Ebdon, and J. R. Bartle. (2004). "Devolution, Fiscal Federalism, and Changing Patterns of Municipal Revenues: The Mismatch between Theory and Reality.” JPART 14(4): 513-533.

MacManus, S. A. (1993). "Budget Battles: Strategies of Local Government Officers during Recession.” Journal of Urban Affairs 15(3): 293-307.

Marlowe, J. (2005). "Fiscal Slack and Counter-Cyclical Expenditure Stabilization: A First Look at the Local Level." Public Budgeting \& Finance 25(3): 48-72.

Mikesell, J. L. (2014). Fiscal Administration: Analysis and Applications for the Public Sector. 9th Ed. Wadsworth, Cengage Learning.

Morgan, D. R. and K. Kickham. (1999). "Changing the Form of County Government: Effects on Revenue and Expenditure Policy.” PAR 59(4): 315-324.

Mullins, D. R. and P. G. Joyce. (1996). "Tax and Expenditure limitations and State and Local Fiscal Structure: An Empirical Assessment.” Public Budgeting \& Finance 16(1): 75-101.

Neiman, M. and D. Krimm. (2009). "Perceptions of Local Fiscal Stress during a State Budget Crisis.” Public Policy Institute of California.

Nelson, K. L. (2012). "Municipal Choices during a Recession: Bounded Rationality and Innovation.” State and Local Government Review 44(1 suppl): 44s-63s.

Nelson, K. L. and J. H. Svara. (2015). "The Roles of Local Government Managers in Theory and Practice: A Centennial Perspective.” PAR 75(1): 49-61.

Nicholson-Crotty, S. (2012). "Leaving Money on the Table: Learning from Recent Refusals of Federal Grants in the American States." Publius 42(3): 449-466.

Nollenberger, K. (2003). Evaluating Financial Condition: A Handbook for Local Government. Washington: ICMA.

Oates, W. E. (2005). “Toward A Second-Generation Theory of Fiscal Federalism.” International Tax and Public Finance 12(4): 349-373.

Oates, W. E. (2008). “On the Evolution of Fiscal Federalism: Theory and Institutions.” National Tax Journal 61(2): 313-334.

Pagano, M. A. and J. M. Johnston (2000). "Life at the Bottom of the Fiscal Food Chain: Examining City and County Revenue Decisions.” Publius 30(1): 159-170.

Peterson, P. E. (1981). City Limits. University of Chicago Press.

Rodden, J. A. (2006). Hamilton's Paradox: The Promise and Peril of Fiscal Federalism. Cambridge University Press.

Rose, S. and D. L. Smith. (2012). "Budget Slack, Institutions, and Transparency.” PAR 72(2): 187-195.

Sokolow, A. D. and P. M. Detwiler. (2001). "California.” Home Rule in America: A Fifty-state Handbook. Krane, Rigos, and Hill Jr. Congressional Quarterly Inc.

Streib, G., J. H. Svara, W. L. Jr. Waugh, K A. Klase, D. C. Menzel, T. J. Salant, J. E. Benton, J. Byers, and B. A. Cigler. (2007). "Conducting Research on Counties in the 21st Century: A New Agenda and Database Considerations.” PAR 67(6): 968-983.

Sun, R. and C. Jung. (2011). "Does User-Charge Financing Reduce Expenditure Levels for the Charge-Financed Services?” ARPA 42(2): 170-185.

Tannenwald, R. (1990). “Taking Charge: Should New England Increase its Reliance on User Charges?” New England Economic Review 56-74.

Tannenwald, R. and J. Cowan. (1997). "Fiscal Capacity, Fiscal Need, and Fiscal Comfort among U.S. States: New Evidence.” Publius 27(3): 113-126.

Taylor, M. (2016). “Improving California’s Criminal Fine and Fee System.” An LAO Report, Legislative Analysis Office, January 2016.

Weingast, B. R. (2009). "Second Generation Fiscal Federalism: The Implications of Fiscal Incentives.” Journal of Urban Economics 65(3): 279-293.

Wildasin, D. E. (2009). “Intergovernmental Transfers to Local Governments.” IFIR Working Paper No. 2009-11. Institute for Federalism and Intergovernmental Relations.

Wolman, H. (1983). "Understanding Local Government Responses to Fiscal Pressure: A cross national analysis.” Journal of Public Policy 3(3): 245-63.

\footnotetext{
${ }^{\mathrm{i}}$ In this paper, nontax revenue refers to general own-source revenue from fees/charges and fines/forfeitures, although it includes various categories such as licenses, interests, special assessment, and sales of property. Fees and charges are grouped into the same category considering the categorization of county financial reports as well as the need for comparison to fines and forfeitures. Although user fees are "sometimes considered in the same category as charges” (Hendrick 2013:221; US Census Bureau), Mikesell (2014) rightfully distinguishes fees from charges by saying that fees are more regulation-based than user charges.
} 
ii California counties provide statewide health and social services programs as agents of the state, designated countywide functions including public safety, public works and elections as well as wide local services such as policing, parks and garbage collection in unincorporated areas (Danielson and Mejia 2011).

iii The major categories of fees and charges in Los Angeles County are law enforcement services (31.7\%) and institutional care and services (21.9\%) and others (23.05\%). Smaller categories include health fees (3.99\%), sanitation services (1.36\%), parks and recreation fees (1.20\%), planning and engineering services $(1.20 \%)$, human services $(0.57 \%)$, road and street services $(0.13 \%)$, and others.

${ }^{\text {iv }}$ However, property tax revenues have been vulnerable to the economy as much as other taxes especially since the early 2000s in California (Bartle et al. 2011).

${ }^{v}$ In order to convert monetary series in constant dollars, the article uses the CPI-U, Consumer Price Index for urban consumers, one of the commonly used inflation measures, which the average change in prices paid for a market basket of goods purchased for consumption by urban consumers.

${ }^{\text {vi }}$ To investigate the moderating effect of the transfer-dependence on the higher levels of government, we include federal grants directly distributed to local governments without passing through state government, while excluding the revenues from other local governments.

vii The fixed effects model is preferred when most variations of dependent variables can be better explained by the variations of residual representing the characteristics of individual panels than by the random residuals with a normal distribution. The between effects models did not provide meaningful results due to low F statistics.

viii The estimation results from the Arellano-Bond model showed a potential influence of past revenue structure without significant changes in estimation of other variables. In addition, the estimation results from the models with alternative dependent variables such as the ratio of nontax revenue to total revenue displayed similar less interesting but consistent findings. The result tables as well as diagnostics are available upon request (or online available). 